\title{
Elections, Identity and Ethnic Conflict in the
} Caribbean

The Trinidad Case

Ralph R. Premdas

\section{(2) OpenEdition \\ Journals}

Electronic version

URL: http://journals.openedition.org/plc/246

DOI: $10.4000 /$ plc.246

ISSN: 2117-5209

\section{Publisher}

L'Harmattan

\section{Printed version}

Date of publication: 14 January 2004

Number of pages: 17-61

ISBN: 2-7475-7061-4

ISSN: $1279-8657$

\section{Electronic reference}

Ralph R. Premdas, «Elections, Identity and Ethnic Conflict in the Caribbean », Pouvoirs dans la Caraïbe [Online], 14 | 2004, Online since 02 March 2011, connection on 19 April 2019. URL : http:// journals.openedition.org/plc/246 ; DOI : 10.4000/plc.246 


\title{
ElECTIONS, IDENTITY AND ETHNIC CONFLICT IN The Caribbean : The Trinidad CaSe
}

\author{
by Ralph R. PREMDAS \\ Department of Government \\ University of the West Indies \\ St. Augustine \\ Trinidad and Tobago
}

Below the surface of Trinidad's political peace exists an antagonistic ethnic monster waiting its moment of opportunity to explode $^{1}$. The image of a politically stable and economically prosperous state however conceals powerful internal contradictions in the society. Many critical tensions prowl through the body politic threatening to throw the society into turmoil. Perhaps, the most salient of these tensions derives from the country's multi-ethnic population. Among the one million, two hundred thousand citizens live four distinct ethno-racial groups: Africans, Asian Indians, Europeans and Chinese. For two centuries, these groups co-existed in Trinidad, but failed to evolve a consensus of shared values so as to engender a sense of common citizenship and a shared identity. Below the veneer of inter-communal camaraderie lurks a sense of deep ethnically rooted sectionalism which pervades the society. After the colonial power departed in 1962, the new state found itself preoccupied by the rival political claims of the

\footnotetext{
${ }^{1}$ For general discussions of Trinidad, politics, see : K. Yelvington (ed.), Ethnicity in Trinidad, London, Macmillan, 1992; I. Oxaal, Black Bourgeoisie Come To Power, Massachusetts, Schenkman, 1968; Ralph Premdas, "Political Succession in Trinidad and Tobago", in The Modern Caribbean, edited by P. Sutton and A. Payne, Baltimore, Johns Hopkins Press, 1992; Percy Hintzen, The Costs of Regime Survival, London, Cambridge University Press, 1989; S.B. MacDonald, Democracy and Development in the Caribbean, New York, Praeger, 1986; Jose Sandoval, "State Capitalism in a Petroleum-Based Economy", in Crisis in the Caribbean, edited by P. Ambursley, London, Heineman, 1983; V. Naipaul, Guerrillas, London, Penguin, 1980; B. Brereton, Race Relations in Colonial Trinidad 1870-1900, London, Cambridge University Press, 1979; D. Wood, Trinidad in Transition, Oxford, 1968; R. Premdas (ed)., The Enigma of Ethnicity, UWI, 1993.
} 
country's two largest ethnic sections constituted of Indians and Africans in antagonistic relationship to each other. This is the basic contradiction in the state coming to occupy center stage in political life defining issues and dominating daily discourse.

Table I:

Population and Ethnic Groups in Trinidad and Tobago

\begin{tabular}{|l|l|l|}
\hline African & 444,804 & $38.91 \%$ \\
\hline Indian & 452,709 & $39.60 \%$ \\
\hline Chinese & 4,322 & $.38 \%$ \\
\hline Syrian/Lebanese & 936 & $.08 \%$ \\
\hline White & 7,302 & $.64 \%$ \\
\hline Mixed & 207,280 & $18.13 \%$ \\
\hline Others & 25,773 & $2.35 \%$ \\
\hline Total & $1,143,126$ & $100 \%$ \\
\hline
\end{tabular}

(1990 Census: Trinidad and Tobago Statistical Office)

The pivotal problem thrown up by Trinidad's multi-ethnicity in part pertains to collective communal interests and sectional identity. Each ethnic section sees its interests differently not only in relation to its symbolic and cultural life but in relation to claims to economics resources. The unintegrated state subsumes a variety of discrete subcultural communities each bound by a configuration of unique social traits that constitute its identity, if only in the imagination ${ }^{2}$. Intercommunal conflict is in fact identity politics expressed as assertions for symbolic recognition and material resources. In turn, at the political level, inter-communal competition reverberates on the issue of establishing legitimate rule in a form of government that does not pose a threat to the survival of another group's identity and interests and that ensures that the values of the state can be equity distributed. The governmental system bequeathed by Britain was anything but an arrangement that guaranteed the fulfillment of these political and cultural aims. Indeed the inherited British parliamentary system was erected on a zero-sum competitive party system that tended to inflame ethnic passions

\footnotetext{
${ }^{2}$ See Benedict Anderson, Imagined Communities, London, Verso, 1983; see also Ralph Premdas, Ethnic Identity in the Caribbean, Toronto, University of Toronto, R.F. Harney Monograph Papers and Lectures Series on Multiculturalism and Ethnicity, 1995.
} 
Elections, Identity and Ethnic Conflict in the Caribbean:

The Trinidad Case

and apportion privileges very unevenly. This internal contradiction in Trinidad's polity stands as its most potent threat to stability of the society. Ethnic dominance in government and identity politics soon became a way of life fraught with an immense undercurrent of sectional alienation for the losers in the competition for recognition and resources.

\section{A. THE SIGNIFICANCE OF THE ELECTIONS}

Each election that came tended to raise anew all the unresolved issues of ethnic equity. As it happened in Trinidad, one ethnic group in an essentially ethnically bi-polar state had captured power and in the perception of the other major ethnic community instituted an order that was ethnically repressive and discriminatory. An election campaign assumed the form of identity rivalry expressed in a collective communal struggle in which the claims of each community as a whole were reignited anew and expressed in uncompromising terms. Repeated victory by one sectional community over the other was not accepted by the vanquished group which withdrew its moral support from the state.

Elections have served as the critical arbiter in adjudicating the rival claims by the main ethno-cultural communities for power and privilege. In Trinidad's multi-ethnic setting however, the function of the election device had been thrown into question on several counts ${ }^{3}$. First, as a means of providing representation to citizens, elections seemed instead to have supplied a fractured public will following communal lines. While democracy is not about government by unanimity and is inherently partisan, for it to operate effectively it must be cast within the context of a larger citizen commitment to the general values and beliefs of the system as a whole. Thus, elections in states that are not deeply divided but share a social consensus are rarely about radical restructuring of the underlying social contract but tend to serve as a ritual that affirm citizen commitment to the political system as well as supply decision-makers for the polity. The voting act then serves symbolically to

${ }^{3}$ For a discussion of the role of elections in multi-ethnic states, see: R.S. Milne, "Elections in Developing Countries", Parliamentary Affairs, Vol. XVIII, No. 1, $1964-$ 1965; Ralph Premdas, "Elections and Campaigns in a racially Bifurcated state", Journal of Inter-American Studies and World Affairs, 1972. 
link citizens to the system and to each other regardless of the party that wins the elections. Issues are moderately debated and rarely so inflame passions that threaten to rip the society apart. All of these latent functions that inhere in the elections institution are enacted only when the larger context of shared trust binds overwhelming majority of citizens and where representative to public opinion and can be periodically changed.

The electoral device with these internal properties, however, was imported into Trinidad from British roots, an environment radically different in social structure from Trinidad. The adaptation of the electoral device to the multi-ethnic society in Trinidad has left important questions unresolved about the roles of representation, identity, integration, citizen commitment, and government accountability traditionally assigned to the electoral system. In particular, representation tends to become communalized so that the party in power symbolizes not the public will at large but sectional solidarity and ethnically particularized interests. Citizen commitment is passionately expressed but communally cleaved so that only one section at a time identifies with the governing regime. The out-section is alienated.

Elections elicit fearsome primordial responses and deeply divisive fears in culturally fractured states. In a communally divided society lacking shared beliefs and identities, all political structures however neutrally designed tend to be tainted and imbued with suspect ethnic motifs and interests. Communal identities are at stake for in defeat the vanquished may witness the marginalization of its way of life. Consequently, the electoral device becomes larger than its original purpose designed for selecting decision-makers. In Trinidad, it was charged that elections became an arena of contesting identities enmeshed in a threat of ethnic domination.

When general elections occurred in Trinidad and Tobago (Trinidad hereafter) on December 16, 1991, few citizens doubted their right to select their representatives. Free and fair elections had taken place since 1946 when universal adult suffrage was first introduced in this former British colony in the Caribbean. After independence in 1962, successive elections occurred regularly, and apart from one near fateful 
Elections, Identity and Ethnic Conflict in the Caribbean:

The Trinidad Case

insurrectionary event in 1970 accompanied by a virtual election boycott in 1971, political succession through the ballot became routine and has been taken for granted. Trinidad became a showcase of democratic practices to much of the outside world. Human rights appeared to be well safeguarded and institutionally entrenched. Accompanying this positive political outlook has been the relative prosperity for the million or so citizens who benefited from the island's endowment of petroleum resources. The high standard of living of the average Trinidadian was reflected in a per capita income of nearly (US) $\$ 10,000$ in 1980 , an amount that placed the country among the most prosperous states in the Third World. Trinidadians indulged heavily in the ethos of a market consumerist society.

Trinidad and Tobago like most Third World countries has however suffered from the ravages of internal ethnic conflict. Development has been derailed by uncompromising ethnic rivalry. Elections have tended to be bound by competitive communal parties and sectionally divided electorates. The upshot has been political instability and a defect in the democratic process itself. While, the competitive multi-party democratic system survived and ethnic electoral politics "stabilized" around the dominance and rule of one of the sectional parties without drawing overt and systematic extra-legal resistance by the excluded ethnic groups, governance by the People's National Movement (PNM) was, however, conducted in the context of a fractured public will; one large communal section, protested against racial repression and discrimination and offered less than token recognition to the legitimacy of the ruling party. A veritable civil war was quietly enacted everyday in routines that contained communal malaise.

It was not until December 1986 in the country's sixth postindependence general elections that an unprecedented break was made with the past patterns of conflict in Trinidad. On that occasion, a multiethnic, multi-class party called the National Alliance for Reconstruction (NAR) won the elections. Trinidad seemed to have broken out of the grip of its double headed internal contradiction bound by invidious racial and class antagonisms. In NAR, a rainbow regime of "one love" was installed 
in the cockpit of power. After five years of rule, NAR returned to the electorate for a new mandate to continue to govern. But by 1991, however, new discontents were unleashed in the society and the "rainbow" consociation of inter-class and inter-ethnic amity was under radical challenge. Strong ethno-communalist sentiments had re-emerged in the wake of economic crisis and the attendant austerity measures that the NAR introduced returned to haunt them in the 1991 general elections.

Was NAR's momentous triumph in 1986 only a temporary aberration or was it long-lasting? In the 1991 elections then, a wider issue with immense theoretical significance had been embedded. Was sectional identity becoming erased by rational issue-oriented politics? Will Trinidad point the way to other Third World countries in overcoming the claims of communalism?

For many the results were long awaited to indicate whether the old form of ethnic rivalry was surmounted and a radically new style of cross-communal politics re-affirmed. Three major parties competed, two anchored in the will of two largest ethnic communities, the other based on cross-sectional appeals. In the 1986 general elections when the ruling NAR dramatically breached all old patterns of ethnic electoral preference in evicting from power the African-Creole based People's National Movement (PNM) which had governed Trinidad since 1956, NAR's victory signaled a new brand of politics pointing to the prospect of primordial ethnic preference yielding to a rational electorate motivated by pragmatic calculations of concrete self-interest.

In the 1991 elections then, the fear persisted that the experiment in a popular cross-communal party which was attained in 1986 was threatened and a new era of re-tribalized ethnic parties was at hand. Yet, many hoped that this would not happen and that the electorate would not return to primordial patterns of party preference and politics.

More than just re-electing office holders then were at stake in the 1991 elections. It was a critical election in the Caribbean. If a communally-bound party were to win, then the promise of illegitimacy, instability, and disunity awaited Trinidad. If NAR, even in its 
Elections, Identity and Ethnic Conflict in the Caribbean:

The Trinidad Case

reconstituted weaker form as a multi-ethic party without a natural ethnic electorate were to win instead, hope of cross-communal cooperation in development was promised.

Since the 1991 elections, three new elections were called. We shall look at these three additional elections very briefly with most of our attention focused on the elections of 1991. It will be useful before we proceed to analyze and evaluate the results of the 1991 elections to give a brief portrait of the Trinidad polity and economy.

\section{B. TRINIDAD AND TOBAgo:}

\section{AN INTRODUCTORY PORTRAIT TO THE ElECTIONS}

The twin-island state of Trinidad and Tobago (Trinidad hereafter) independent since 1962 was first claimed and colonized by the Spaniards on July 31, 1498, until it fell under British control in 1797 where it stayed until the mid-twentieth century. For about four hundred and fifty years, Trinidad evolved mainly as a territorial appendage of and as a dependent supplier of raw materials to its European metropoles. Production of coffee, cocoa, cotton, and sugar was done under a mode of plantation production that led to the implanting of an immigrant multiethnic population. The indigenous Amerindian population was recruited and eventually enslaved to meet the labor needs of the colonizers. The Arawaks and Caribs, in the long trek of Spanish colonial control, unable to adapt to the work regimentation of the plantations would be practically decimated. The primary product grown was sugar but other exportable plantation crops also included coffee, cotton, and tobacco. The labor came from forced African servitude through the iniquitous slave trade.

When slavery was abolished in 1833 , the colonists were forced to find a new source of labor. Because both Trinidad and India were colonies of Britain, this facilitated the recruitment of Indian indentured laborers from India. Asian Indians (Indians hereafter) then came in shiploads for several decades. By 1917, when the Indian indenture scheme was terminated, some 144,000 Indians were imported into Trinidad. Most were Hindus from north India, but about $15 \%$ were Muslims. Indians emerged as the backbone of the plantations. While 
some Indians opted to return to India at the end of their indenture, most chose to remain as permanent residents of the colony. By 1875 , about $87 \%$ of the sugar plantation laborers were Indians. Autonomous Indian villages arose around the plantations and Indians became essentially rural dwellers. The emancipated Africans developed contempt for the Indians who had willingly submitted themselves to the degrading regimen of the plantation. Indians in turn regarded the Africans as "outcasts" who had readily accepted and acculturated to the ways of the oppressor. Herein, then, would the first seeds of Indian-African antipathy be born. Most Africans migrated to the urban areas where they evolved as a skilled and semi-skilled proletariat and adapted to English ways.

Thus then, with the arrival of Europeans, Africans, Indians, and Chinese and added to by a significant group of "mixed races", would a plural multi-ethnic society be forged in Trinidad. African slavery and Indian indenture served as the twin bases on which the successful colonization of the tropical terrain occurred. A workforce of culturally different immigrants from the Old World was recruited to labor on plantations which provided the nucleus for a new society. Partly because of the superior economic and military power of the Europeans, a colorclass stratification system evolved whereby things English and white prized were and became the measure of social value.

The pluralized ethnic structure which came into being in Trinidad was reinforced by multiple coinciding cleavages expressed in patterns of occupation, residence, and cultural orientation among each of the segments in the immigrant population. By the turn of the $19^{\text {th }}$ century, a communally oriented multi-ethnic society was fashioned; with some modifications, most of its essential features have persisted into the present. While European influence has remained pre-eminent (Europeans are collectively called French Creoles today and they are nearly all locally born and bred), inter-communal rivalry between Africans (locally called "Creoles") and Asian Indians (called "Indians") would emerge as the dominant feature in inter-ethnic relations in the state. In addition, a complex of almost exclusive ethnically bound cultural and social voluntary associations has emerged to consolidate the split personality of 
Elections, Identity and Ethnic Conflict in the Caribbean:

The Trinidad Case

the new order. Negative stereotypes held of each group by others constitute the main medium of inter-ethnic perceptions which in turn provide a vocabulary of racial slurs that reinforce ethnic exclusivity.

While sugar production is relatively old, petroleum was discovered at the turn of the twentieth century and slowly emerged as the dominant primary producing export product eclipsing sugar, coffee, and cocoa. Over centuries of evolution as a producer of primary products for an export market, the economy of contemporary Trinidad reflects this historical imprint by its heavy reliance on oil, gas, petroleum and sugar for its survival. In a peculiar twist of events that can only happen in a plural society, ethnic identity and the economy became enmeshed: sugar production has come to be associated with the Indians, oil with Creoles, and big multi-national business corporations with French Creoles. In the twentieth century, the Trinidad economy attained new levels of complexity registered especially in the development of a large public sector employing about 60,000 public servants about $70 \%$ of whom were Creoles and mixed races. Indians did not remain with sugar even though most sugar workers and planters are still Indians. Most Indians have gravitated into small businesses, trades, teaching, and the professions.

Politics in Trinidad, like the economy, developed in terms of the underlying ethnic delineations in the state. When mass representation and a party system became a part of democratic politics after centuries of colonial rule, the fragmented social structure shaped political orientation and partisan preference. Ethnically based parties emerged and exacerbated communal tensions. Inter-ethnic distrust would render nation-building and economic development problematic. In the 1950's, two major parties, the People's National Movement (PNM) and the Democratic Labor Party which would later become the United Labor Front and in the contemporary political scene became the United National Congress were organized mainly around the Creole and Indian communities respectively. The Creole-based PNM party headed by Dr. Eric Williams led the colony to independence in 1962 and governed the state through several elections until December, 1986. During the long period of PNM rule, the Indian community bitterly complained about 
ethnic discrimination as attested to by the exclusion of Hindus from cabinet appointments and the overwhelming stacking of the civil service by Creoles.

When oil prices were high in the 1970's, Trinidad enjoyed unprecedented prosperity and the PNM became entrenched. In the 1980 's, however, with the plummeting of oil prices, a steep recession led to the eviction of the PNM from power in the 1986 general elections. The victorious party was called the National Alliance for Reconstruction (NAR). It was constituted of an unprecedented alignment of disgruntled Indians and Creoles. It represented that elusive multi-ethnic formation which had so far failed to appear in Trinidad's modern mass politics. NAR called itself "rainbow party" bound by "one-love". Its ethnic unity was short-lived, however. About one year later the NAR was fatally split between an Indian group led by Basdeo Panday and the Creole group led by Prime Minister Robinson.

\section{THE 1991 Elections}

\section{a. The Structure of the Elections:}

Parties, Issues and the Campaign

In the 1991 elections, the main actors competing for office consisted of three parties: the (National Association for Reconstruction) NAR, (People's National Movement) PNM and (United National Congress) UNC. Two main parties, the UNC and PNM, erected around a core of Indian and African constituents respectively, had dominated Trinidad's politics since 1961.

The PNM was launched in 1956 as an anti-colonial mass movement by historian academic Dr. Eric Williams. The party's charter proclaimed a commitment to promote equity in a multi-racial society: "We are rather a rally, a convention of all and for all, a mobilization of all the forces in the community, cutting across race and religion, class and color, with emphasis on united action by all the peoples in the common cause". The promise of a cross-cultural and inter-ethnic society under PNM rule for seven successive terms of office covering thirty 
Elections, Identity and Ethnic Conflict in the Caribbean:

The Trinidad Case

years of uninterrupted rule was however belied by the fact that the party became preponderantly uni-ethnic in composition and support.

From a small nucleus then in 1956, the PNM would become bigger beginning with its victory in the 1956 general elections in which it won 13 of 24 seats. The PNM led the colony to independence in 1962 and for six consecutive parliamentary terms served as the ruling party until 1986. To the African communal core, the PNM while in power would add the Mixed Races, Europeans ("French Creoles"), Chinese, and a significant slice of the Indian middle class. Wielding undisputed paramountcy over the polity and society in its control over jobs, contracts, and other values, the PNM at once became a tower of strength and place of reverence in periods of plenty and a source of all $\sin$ in times of adversity. An immense target, it was easily bludgeoned into humiliating submission in 1986 when it was only able to obtain only 3 out 36 seats in Parliament. In the wake of steep economic decline, the PNM was weakened and widely perceived as corrupt and incompetent. Dr. Williams had died in 1981 and the loss of his charismatic presence coincided with the degeneration of economic well being in the society. Indians as a whole saw the PNM as an instrument of ethnic repression and in 1986 they would join forces with other dissident groupings in dislodging the PNM from power.

NAR, the ruling party from 1986 to 1991 , led by ANR Robinson was formed in 1986 from three opposition fragments pitted against the PNM. The three elements were: the United Labor Front which was the Indian-based mass party led by Basdeo Panday; the Organization for National Reconstruction which was a multi-ethnic middle class party led by former PNM Stalwart Hudson Phillips; and the Democratic Action Congress (DAC) led by another ex-PNM cabinet member, ANR Robinson. Although, according to its constitution NAR was a unitary party in which its constituent components had submerged their respective identities, in practice it was a loose confederal combination of unintegrated parts. The PNM was their common enemy and raison d'être. 
In the historic December 1986 elections, NAR served itself up as the "rainbow party" committed to "one love" in the promise to replace the African-based PNM with a merging of identities in an authentic multi-ethnic party. In Robinson, an African leader was found; in Panday, an Indian leader was recruited; and in the ranks of the ONR leadership the Mixed Races and French Creoles had representation. In bringing the final party into existence, no formula was agreed upon to share the spoils of power should NAR win. In fact, not even NAR itself expected to win. NAR did win by a margin of 33 seats to 3 . But for a variety of personality, ethnic, and ideological reasons, the ULF segment led by Panday was expelled from the NAR just one year later throwing not only the ruling in crisis but the nation which was euphoric in giving NAR a decisive victory.

The United National Congress led by Panday was a direct descendant from NAR but in fact it had a larger pedigree going back to the mid-1950s. In this continuity, the UNC owed its lineage to Indians who constitute one of the two largest ethnic communities in Trinidad and who were organized from the very inception of mass politics in anticipation of self-government in the 1950s. The UNC's votes were concentrated in the central sugar growing plains where Indian parties since 1961 have been able to obtain about a third of the parliamentary seats.

The essentially three-way contest was a mixture of old and new motifs in Trinidad's politics. The PNM and UNC represented the old ethnic politics; these parties could count on a solid core of ethnic constituents to vote for them. The NAR represented, at least in its initial formation in 1986 to 1988 prior to the expulsion of Panday, a genuine multi-ethnic grouping that had significantly disengaged many voters form their traditional cultural partisan moorings. The original NAR phenomenon with its multi-ethnic following had caused a new model of party representation to be founded in Trinidad. While the old parties nominally had claimed multi-ethnic constituents, the fact remained that Africans and Indians under the old order remained loyal to their respective parties. By the victory of the original NAR in December 1986, 
Elections, Identity and Ethnic Conflict in the Caribbean:

The Trinidad Case

a new example of cross-communal partisan coalition had emerged as the method towards electoral victory.

Hence, in 1991, both the PNM and UNC undertook strenuous efforts to refurbish their manifestoes, rhetoric, and frontline personnel to reflect multi-ethnicity. The PNM called itself a "new PNM" attempting to distance itself from the ethnic bias, corruption and incompetence of the PNM under the old guard that was defeated in 1986. The UNC also attempted to present a multi-ethnic front. This new multi-ethnic image in PNM and UNC was a hard act to maintain, however, especially as the elections heated up and the election dateline approached. The Robinsonled NAR which had also sought to refurbish its tarnished image after the Panday expulsion was seen by many as the party with a cross-section of ethnic support potentially able to win as it did in 1986. NAR, however, did possess its own tinge of ethnicity, however, seen by many as the party of mainly upper middle class Mixed Race persons as well as French Creoles to which was added parts of the African and Indian middle class.

\section{b. Ethnic Appeals and the Campaign}

In a state constituted of several communal sections which bore strong antipathies towards each other, the ethnic identity factor always hovered as one of the most fearful and powerful forces that could have convulsed the society into total turmoil. In the 1961 general elections in Trinidad and Tobago, communal strife had reached unprecedented proportions with the PNM charged with violent organized hooliganism and the DLP with the threat of using arms. The African-East Indian chasm ordinarily regulated in rituals of avoidance and formal courtesy in normal daily interaction tended to deepen during elections in part because the political parties were polarized along ethnic lines. After 1961, racial tensions abated although it persisted. The restraint in the open use of racial appeals derived after the 1961 elections stemmed mainly from the foregone conclusion that the PNM was the winner in all future elections. Even so, the ethnic monster was not fully restrained as a mobilizer of voters in the elections that followed 1961. It tended to be subterranean and subtle but always present and salient. Since 1961, then, a modus operandi had evolved in inter-party affairs between the two 
major ethnic parties so as to limit the expression of ethnic claims and racial accusations publicly. In its place a new vocabulary and symbolism had evolved that disguised the ethnic discourse in a contrived theatre of overt tolerance.

In the 1991 elections, this ethnic disguise was evident but at times it bolted the barriers of ritual restraint thrusting into the open and threatening to destroy the seeming tolerance in the society. Towards the final days of the elections, one newspaper reporter noted that the "Medusa of the elections - race, ethnic division - has reared its forked tongued head quite high this time"4. Another of the major papers also pointed "persistent allegations of racism". The parties exchanged charges and counter charges of covert ethnic appeals. But what was clear as one reporter noted was that they were all doing it, "ironically, at a time when all the parties in the race has been seeking to convince the electorate that each is the only true national party" ${ }^{\prime \prime}$. The seeming hypocrisy in this habit of saying one thing and doing another in the area of race could easily explained by the conventions of outward ethnic probity and inward racial rivalry that had evolved in Trinidad and Tobago.

In the 1991 election campaign, the vocabulary of ethnic appeals that attempted to parade in disguise took many forms but fooled no one. Panday spoke of "alienation" as one of his foremost issues euphemistically referring to alleged racial discrimination by the PNM and the NAR governments against East Indians. Manning spoke of the need of a "caring" regime referring to the alleged disproportionate share of adversity that Black voters experienced during the NAR term in office. Robinson spoke of "dependency syndrome" in his condemnation of alleged PNM practices that reduced many Africans to conditions of dependence on political patronage for survival instead of dignified development. NAR also spoke of "participation" in his appeal to East

\footnotetext{
${ }^{4}$ G. Alexander, "When Heaven Smiled", Guardian, 28/11/1991, p. 4.

5 "Call for Vigilance", Guardian, 12/12/1991, p. 8.

${ }^{6} \mathrm{G}$. Alexander, art. cit.
} 
Elections, Identity and Ethnic Conflict in the Caribbean:

The Trinidad Case

Indians to vote against the UNC which had kept them in futile opposition in Parliament. The verbal disguises and other symbolisms assumed many forms and variations. Sometimes they were open such as the effort of each party to parade an ethnically mixed collection of candidates and to discuss issues that addressed the needs of all communal sections. Panday, for instance, representing Indians mainly, vigorously advocated programs of economic amelioration to assist urban blacks. Manning pointed to a "new" PNM. The verbal foliage that offered a front for inter-ethnic equity served as an important ingredient in instilling ethnic camaraderie among party workers on the campaign trail. Everywhere no effort was spared to show East Indians and Africans sharing campaign platforms and saying amicable innocuous things about national unity.

All of this overt symbolism and ceremony, however, was belied by a different behavior at the grassroots level. The very fact that the PNM and UNC canvassers tended to carry a map of supporters and nonsupporters defined in ethnic terms and which in turn governed their canvassing strategies attested to the salience of ethnic identity in the mobilization of electoral support. This resulted in a campaign structure that was basically communalist. Indian canvassers for the UNC were chosen to canvass in Indian homes and neighbors in the same way as African canvassers for African areas and homes. Apart from a pragmatism that informed such selectivity, there was also fear of breaching territorial codes of personal safety. That apart, Indians and Africans could not seriously convince each other that they could be sincere about crossing the ethnic divide even when they were in the same party. At the intimate level of canvassing involving entry into homes not much needed to be said by canvassers to electors about the need for communal solidarity and loyalty. The voter who breached these principles of solidarity openly risked ostracism, even violence. This sort of collective communal pressure served not only to reinforce communal identity and solidarity but in the long run perpetuated the ethnic division as the normal state of affairs in which to live, love and die in Trinidad. It will be useful to look in some detail at how the campaign has been 
conducted since it is at this site of struggle that ethnic identity is organized and mobilized.

The organizational format in campaigning for each party was similar in structure but different in delivery capability and traditional practices. The three major parties penetrated each constituency with their basic "grassroots" party unit or group located around each polling division. Each constituency had a number of polling divisions and each had put in place a constituency executive group which in turn was subdivided into polling division units equipped with its own staff canvassers. It was the task of each constituency party group to map comprehensively its polling divisions so that a portrait of the ethnic, economic, and religious characteristics of voters could be ascertained. These data serve as the raw materials for identifying three categories of voters: "core" or loyal supporters; marginals in need of conversion; and "die-hard" opposition party supporters. As a matter of first priority, each party had attended to its core supporters and thereafter focused its efforts on the "marginals" or floating voters. Voters and constituency areas which are perceived as constituting opposition "faithfuls" and strongholds tended to be neglected in practice. As a result of this tactic of selective canvassing, and in a number of cases party canvassers were openly afraid to enter an area perceived as belonging to the domain of an opponent, most constituencies throughout the country had not been criss-crossed comprehensively by all the parties. In an election where ethnic preference became salient, the consequence of this practice was the reinforcement of old voting patterns. In the 1991 elections, the presence of NAR as a multi-ethnic party without a "natural" traditional ethnic constituency such as was associated with the PNM and UNC meant that the old selective practices of ethnically directed campaign behavior were partially breached but not so much by the PNM or UNC as by NAR in desperate quest for votes wherever they could be found. The PNM and UNC had to protect their old ramparts from NAR raids.

The method of access to each voter and household was through individual house-to-house canvassing and small group, household and neighborhood gatherings called "cottage" meetings. Parties such as the 
Elections, Identity and Ethnic Conflict in the Caribbean:

The Trinidad Case

PNM had fashioned the "cottage" meeting into an effective tradition with a semi-permanent cadre of grassroots party activists and homes always available for activation and mobilization especially in loyal core areas. It is at this level of intimate inter-personal communication that each party had hoped to consolidate its support. When it seemed that NAR as the ruling party with its access to a huge reservoir of resources was about to outspend other parties at the level of the mass media campaign, the PNM reacted by saying that it was going to deploy fifty grassroots canvassers for every fifty dollars that NAR spent on advertisements. The PNM bragged that it could mobilize as many as one hundred thousand $(100,000)$ canvassers and was aiming at getting their campaigners into seventy five per cent $(75 \%)$ of households. Lacking funds, the UNC similarly converted this deficiency into a virtue promising to minimize buying mass media "propaganda" and depending more on "personal touch". In every case, however, the parties realized that the campaign canvassers was to be located at the very front line of their efforts. Often canvassers came on "blitzes" moving as waves of small groups sometimes in the company of the candidates calling on the homes of voters for quick visits. Most often these were periodic superficial affairs which were intended to convey the impression of a popular party presence.

The mass of canvassers who made "sweeps" through a polling division was often supplemented at a more intense level by solicitations by community leaders. This technique was particularly intended for the conversion of "marginals" and "floaters". In every constituency a roster was maintained of community leaders such as schoolteachers, preachers, businessmen, sports leaders, senior civil servants, and social workers, many of these persons serving as officials in local clubs and sociocultural voluntary organizations. These were the party's influential from whom the party's polling and constituency committees were composed and often times the source from which candidates were selected. Usually, a party's candidate for a constituency was someone with a long list of service in community organizations. Even where a candidate lacked these credentials, he or she was still sold to the constituency in this wrapping 
of community service. Community leaders, constituting a critical tier of citizenry, operated in a network exerting continuing influence on behalf of the party at the grassroots. When a party sought to penetrate another's stronghold of support, often this was done at the level of community leaders. During the 1991 elections, several of these persons long associated with one or the other party, when converted, were paraded on party platforms as proof of extensive party support.

The canvassers and community leaders were usually the carriers of the party's paraphernalia of buttons, T-shirts, posters, and messages. They made the party literally visible in the constituency constantly parading and placing on display all the physical symbols of the party's campaign presence. The collection of party activists, party paraphernalia, music, cottage meetings, and visible up and down movements especially within areas that were already captured as well as small townships, markets and shopping malls all added up to a formidable phalanx and in some constituencies they engaged in fierce competition for party allegiances at the micro-level of the campaign. The PNM, out of power was able to devote full time to ongoing grassroots campaigning and sustained this exercise of ongoing party activism in its basic form for almost a year prior to the elections. The UNC was not able to do this overtly or as comprehensively as the PNM mainly because it was embroiled in its own internal party in fighting. But the UNC had its network of canvassers and community leaders lying dormant for activation as the election date came closer. NAR was able to recruit a number of converts at the grassroots level from both the PNM and UNC. Through a variety of programs sponsored by the government such as National Service, YESS, ECHO, and cooperatives, NAR has assiduously weaned away a number of PNM and UNC supporters. It seemed to many observers that NAR had succeeded in a large number of areas in displacing old voter loyalties through its assiduous activities among community leaders at the grassroots. It was however, not clear how many of these persons were real converts to NAR and how many enlisted for jobs and patronage. 
Elections, Identity and Ethnic Conflict in the Caribbean:

The Trinidad Case

At a macro level in support of the grassroots political organizations were party advertisements and events which served to link all the constituency and sub-constituency groups into an integrated dynamic national unit. Among the activities of the macro party campaign were mass meetings which were often attended by party activists from other constituencies and on whose platforms speakers and candidates from other constituencies appeared. The mass meetings tended to occur at various levels ranging from individual constituency meetings to regional and national gatherings. These mass gatherings were all characterized by a level of theatre that maximized the party's image as a popular, multi-ethnic, vibrant and optimistic organization. The staging was marked by party music arranged for the occasion; the speakers were well orchestrated so as to include local leaders and national figures, small parochial issues and national debates, and in all cases, a major effort was made to have a flamboyant display of party flags, buttons, and placards in concentrated mass formation. The design of this show was often a work of art high tech entertainment intended to lure everyone to come for a social as well as a political treat. The idea was in part an image of party popularity and strength.

Music was an integral and indispensable part of the campaign at the macro level mass meetings. In a multi-ethnic country, the accompanying tunes came from the respective cultural communities, taking the form of tassa drumming and "chutney" tunes from the East Indian section to "pan (steelband) beating" and "calypso, soca and kaiso" songs from the African Creole section. One example that was well reported by the press illustrated this combination at work: "Tassa drums held sway. Near the podium a Jour Ouvert (Carnival) style 'engine room' (rhythm section) supporting Hilda Goodial got ready to strike up. Panmen rivaled tassa drums, beating iron with a vengeance. The group rivals the tassa for attention and calls forth sinuous swivels and swiveling gyrations from a head-tied East Indian lady"

${ }^{7}$ G. Alexander, "When Heaven Smiled", Express, 15/12/1991, p. 4. 
Some candidates composed their own tunes but each party had adapted their songs for the occasion of the election and the themes of their campaign. For NAR, it designed a special tune called "Attack with Full Force" invoking the brave words that its leader Robinson had used calling for the military counter support when he was held under guns of his captors in the Red House (Parliament) during the July $29^{\text {th }}, 1990$, when some Muslims attempt to seize power in Trinidad and Tobago. NAR had commissioned other calypsos such as "Robbie is the Boss and Give Us Five", but he was not to be outdone by the PNM which had a long history of coming up with catchy tunes such as "Not a Dam Seat for Dem" that devastated its rivals in the 1981 general elections. In 1991, the PNM designed "Never, Never Say NAR Again" and "Now is the Time", among others. The UNC used the old NAR catch tune from the 1986 campaign titled "Vote Dem Out, Nani Wine" and a dub of Bob's Marley's "Three Little Birds" accompanied by tassa drums. In all of these cases Trinidad and Tobago's tradition of carnival and music came in handy during the elections.

Another important aspect of the campaign at the level of mass meetings was "picong" and "bacchanal". This local medium derived from an oral tradition of story telling was a combination of humor, hate, slander, sex and politics. Speakers engaged the crowd in "street theatre" as they slurred the reputation of their adversaries by innuendoes and picong that evoke emotional rapture, uncontrolled laughter, horror and tears. It was expected from the crowd that they be served up with a form of picong in exchange for the hours of listening to political propaganda. Panday, the picong artist leader of the UNC expressed it thus: "When I went to the Tunapuna meeting and I see the crowd on a high, I couldn't go there and talk manifesto. They would pelt me with rotten egg. I have to give them their picong and bacchanal",

Each party had its own set of picong which it employed to caricature its adversaries making even sacred partisan claim an object of ridicule. Many of the stories were invented and assigned to some

${ }^{8}$ K.D. Waterman, "No Laughing Matter", Express, 15/12/1991, p. 11. 
Elections, Identity and Ethnic Conflict in the Caribbean:

The Trinidad Case

mysterious source and often they could irreparably injure the reputation of candidates. Trinidad and Tobago's politics, however, especially during campaigns for office is not a tea party but tends to be peppered as in the 1991 elections by rumor, innuendoes and gossip.

In order to bridle the excesses of "picong" as an established custom from degenerating into open character assassinations and even racial conflagration, attempts were made during the 1991 election campaign to impose ethical standards. The Inter-Religious Organization of Trinidad and Tobago, an ecumenical body representing all of the major religious faiths in the country issued a set of guidelines as a code of conduct to restrain the parties from election excesses ${ }^{9}$. NAR announced that it was appointing a group of lawyers specifically to litigate against any party casting defamatory aspersions on its candidates. This became necessary in part because both PNM and UNC candidate had intended to implicate NAR in drug trafficking in Trinidad and Tobago. This, however, was not enough to constrain widely used allusions to NAR as the alleged party of drug pushers who depended on drug lords for campaign funds. Panday had openly called on NAR to give all of its candidates a drug test. The UNC, however, utilized the idea of a code of conduct to stifle the dissenters in its party ranks. The UNC code, while calling for a voluntary banning of "bad talk" and "mauvaise langue", in the same breath warned that no member of the UNC should use abusive, offensive, or derogatory remarks about other members in the presence of the public ${ }^{10}$. Caught in an internal wrangle that had threatened to tear the party apart just before the elections, the UNC code of conduct was seen as a ploy by Panday to limit the damage that this intra party adversaries were threatening to unleash on his leadership.

At the macro-level, the parties orchestrated a media program involving carefully designed market-oriented advertisements placed on radio, television, and the printed media. While under the rules of the Electoral Commission an individual candidate could not spend more than

\footnotetext{
${ }^{9}$ IRO, "Elections Code", Guardian, 01/08/1991, p. 13.

${ }^{10} \mathrm{G}$. Alexander, "28 days of Whirlwind Activities", Guardian, 15/12/1991, p. 11.
} 
five thousand dollars $(\$ 5,000.00)$ for campaigning, no limits were placed on the expenditure of the parties. At the macro-level, then, the parties expended large undisclosed sums to adorn their main leaders, and to project their key issues and their main appeals. The relative financial capabilities of the parties were often displayed at this level. How each of the major parties combined these broad modalities in the repertoire of campaign techniques in large part distinguished them as unique organizations. NAR hired the firm Atlas Advertising which had been employed to great effect in the 1986 campaign. The PNM hired the services of two firms: UNO Advertising and All Media Productions Ltd, while the UNC did not avail itself of any marketing agency. The NAR media assault had outstripped that of the other parties which charged that NAR lacked grassroots following and was intent on distorting through mass propaganda and modern psychological methods the minds of the electorate. NAR responded to the PNM charge arguing that it was the PNM which had invented lavish campaign spending when it was in power and that the only purpose of its hiring an advertising agency was "to tell the truth about the NAR and about the Opposition's intentions"1 .

The PNM conceived its role in terms of a "crusade of foot soldiers" to storm the electorate with a human wave assault because it anticipated a blitz of flashy advertising and promotion messages from NAR. The UNC lacking in the services of an advertising firm and relying mainly on posters charged that the NAR and PNM media campaigns were sponsored separately by the two main daily newspapers, the Express and Guardian, respectively and by the large business conglomerates. All the parties used these macro methods but NAR and PNM hired public relations firms to craft their assault on the public psyche.

NAR clearly relied heavily on an ample supply of mass media methods more so than the other parties. Around its key issues, it isolated certain topical words and phrases which were prominently exposed and hammered into the minds of the electorate through a large number of

${ }^{11}$ C. Sankar, « Men vs. Money », Express, 02/06/1991, p. 9. 
Elections, Identity and Ethnic Conflict in the Caribbean:

The Trinidad Case

advertisements. For instance, the key words, phrases and sentences include in reference to itself: Party of Performance; Efficiency and Competent Management; Integrity; Thrust; One Love. These words were so crafted that they soon could be used alone as symbolizing the NAR's presence and image. With reference to the PNM which it saw as its chief opponent, it employed a number of negative imagery: "Ready to Go Bankrupt Again?", "If you want to fete Hire the PNM", "You Better Keep Them Out", "Santa is Coming to Town", all of them focused on the PNM's old record of excess spending and alleged corruption during its tenure in office. The PNM aiming its arrow at the NAR used the following sloganised words: "Sensivity", "We care", "Are you better off today than in 1986?", "The tide has turned", all playing on the impact of NAR's austerity measures. Much of the media attack was confined to the NAR versus PNM polarity in the electoral contest. Cartoons and Christmas carols were integrated into the media messages.

The UNC which conducted a late and comparatively low keyed mass media attack decided to aim mainly at the NAR. This meant that NAR was assaulted from two virile fronts simultaneously. It was argued that the UNC and the PNM had a "sweet heart" relationship which meant that they hardly criticized each other while lambasting the NAR together. Whether this was deliberately orchestrated or not was not proven during the elections (but admitted afterwards) but it occurred to the NAR's discomfiture. The UNC assigned to itself the appeals that it was the "Party of the People" and argued in a jingle the "UNC Time Had Come" to run the government since the "PNM had its Day and NAR had its Say". Some of these UNC advertisements appeared in the main weekly newspapers during the very last week of elections. The UNC seemed to have had the sympathy of the well distributed weekly, The Mirror.

Towards the final days of the campaign, the mass media macro method assumed fulsome proportions so that the electorate was blanketed by a collective assault that reduced the parties to certain skeletal symbols and slogans which caricatured their total existence to a few gross impressionistic outlines as complete organizations. NAR which was on the ropes literally having been bludgeoned by both Opposition parties, 
resorted to apocalyptic innuendoes in the mass media suggesting in notable advertisements which occupied full pages with only a few words with the blank space depicting the end of the world for Trinidad and Tobago should the PNM or a PNM and UNC coalition come to power.

In the highly charged atmosphere of an election campaign, with each party engaging in batteries of dubious charges and counter charges, it was difficult to contain the enter event to peaceful procedures. Further, the stakes were high in the loss or gain of the apparatus of government that included offices, jobs, contracts, preferment, symbolic gratification and above all power over the policy direction of the state. Fortunately, even though an undercurrent of claims was advanced that the NAR was a party of the privileged and the PNM and the UNC were parties of the non-white proletariat, the partisan competition contest was not influenced by starkly defined polarized ideologies and beliefs. Neither was race overtly salient, even though the latter was to emerge as such in the final days of the campaign. From all of this, the ground was set for a moderately pitched campaign. Despite this, it was almost inevitable that at some point the bounds of control would have been breached beyond verbal bickering by violence and sabotage. In the 1991 elections some of this did occur but failed to cumulate into a cataclysmic momentum and in the end proved to be sporadic and controlled.

The first act of violence which initially contained ominous portents occurred at Woodford Square, the country's traditional premier public arena for speeches, demonstrations and similar mass political events. NAR, the ruling party was launching its first major initiative in the declaration of electoral war in the campaign for votes. A massive crowd was gathered and all of the main luminaries of the party were in attendance in a display of a well orchestrated theatre of music, applause, and emotions. This was covered comprehensively by all the mass media. NAR wanted to make a winning impression on the population. It was in this initial sortie that NAR felt a tone would be established, and riding on a recent poll that showed them ahead of all the other parties, it hoped a trajectory would be triggered carrying it to victory. It was during the critical speech by the Prime Minister Robinson, the NAR leader, that a 
Elections, Identity and Ethnic Conflict in the Caribbean:

The Trinidad Case

huge fire was set ablaze on the Chamber of Commerce and Industry Building that adjoined Woodford Square. The conflagration significantly derailed the entire NAR event as the raging flames brought a quick and premature end to this major campaign event. The timing of the fire in the midst of the speech by Robinson and the location of it in the building of the Chamber of Commerce which only a week earlier had endorsed the policies of the NAR government strongly suggested a scent of sabotage. In the headlines of the newspapers the next day, NAR in fact laid blame for the fire on political sabotage without naming the accused party. What was significant was that an element of fear was injected in the election campaign at its very outset. Fortunately, while the PNM dismissed all oblique innuendoes that assigned blame to it, none of the parties pursued the matter.

While the flames of the first political fire were allowed to die, its effects were immediate in the sorts of security procedures that the parties had put in place around their mass meetings and physical facilities. At each of the major NAR meetings, for instance, a contingent of security officers was situated so as to protect the event from sabotage and assault. NAR again would experience a second disruption when at another major meeting at the Midmarket Mall in Chaguanas in the heart of the sugar belt, its electrical transmission system was sabotaged. The UNC, about a week later, holding a meeting in the Fyzabad constituency experienced an event similar to Woodford Square when a fire station was put alight during the course of the meeting. The two fires accompanied by the established party surveillance and security systems occurred separately many days never assumed enough significance so as to divert the electorate from the issues that were being discussed by the parties and the heavy canvassing that was mounted throughout all the electorates. There were two instances of shootings which drew some attention. In the Laventille East Constituency, a NAR candidate was dragged out of his house and shot in the head, and in the Oropouche Constituency, a security guard around the house of the NAR Minister of Tourism was shot. These events drew some attention but failed to trigger a shooting war. The events were treated as aberrations. 
It was not until the final seven to ten days before polling scheduled for December 16, that violence again asserted itself. It seemed that certain constituencies in particular were more prone to excesses of heckling, the defacing of party posters, throwing of missiles, and physical acts of violence and intimidation. In the San Fernando West Constituency the worst of these occurred when the NAR candidate Dr. Allen Sammy was physically wounded by stone throwing. It was here also that the PNM charged that a group of its activists while putting up posters were beaten and wounded by NAR partisans. There were isolated cases of beatings such as occurred when an elector heckled the woman PNM candidate in the Port of Spain South Constituency and when similarly a person was beaten when heckling the NAR candidate in the Tabaquite Constituency. It was these little events which had begun to occur more frequently towards polling day that led one of the two major daily newspapers to take note and warn that "suddenly a series of disturbing and unsavory incidents is threatening to mar the elections campaign just a few days before the balloting"12.

While it was true that violence was sporadic during the campaign and never got out of control, it is important to point out that an aura of threat violence hovered over the elections. Prime Minister Robinson threatened at one stage to invite international observers to witness the elections in part to deter flagrant efforts to turn the election campaign into a zone of turmoil. NAR in particular, felt it was not likely to withstand the combined physical assault from both the PNM and the UNC, even though it seemed clear, as the PNM leader had indicated that it was not in the best interest of the PNM to provide an excuse for the NAR to postpone the elections. This was especially critical to the PNM when one week before the elections, all polls indicated that the popular tide had turned in its favor. The PNM, confident of victory, feared that NAR would call off the elections should violence rear its ugly head. Over and over again the PNM leaders strongly advised their followers to stay calm.

12 «Call for Vigilance », art. cit., p. 8. 
Elections, Identity and Ethnic Conflict in the Caribbean:

The Trinidad Case

If physical violence did not emerge in a sustained and cumulative manner so as to mar the election campaign, the same could not be said of the ethnic and racial factor.

The efforts of NAR as a party without an ethnic base, even though it seemed to have solidarity-type support among French Creoles and well-off mixed races suggesting an "ethnic" following, were aimed at breaking the ethnic hold on traditional political preferences of the electorate. In a campaign that progressively shifted away from the overt rational discourse over issues towards an intensification of emotions around communal solidarity, the NAR almost collapsed in the final lap of the election race. The mass meeting held by the UNC at Aranguez Park and by the PNM at Constantine Park two days prior to polling day were overwhelming uni-ethnic in composition and showed how voter allegiance had crystallized around ethnic preference. By comparison, the final NAR meeting at Woodfort Square, although mixed and middle class in composition, lacked the electricity and collective verve that marked the virtual "tribal" meetings of its opposing rivals. It seemed as if the winds had been emptied out of NAR's sails. None of this happened, however, by abandoning the overt trappings and vocabularies of interethnic amity.

The election campaign had culminated in an unequivocal assertion of ethnic solidarity ${ }^{13}$. It seemed clear that with the parties rapidly approaching the winner's line, in that moment of truth all flirtations with inter-ethnic unity that had exited in a twilight zone of theatre were momentarily set aside for a primordial communion with the ancestral party. This emotion was always there at the inner concealed level of the campaign although its symbols and official party doublespeak solicited its sympathies. Once the polls one week before the elections unanimously showed that the PNM was likely to be the winner

13 See Ralph Premdas, "Identity in an Ethnically Bifurcated State: Trinidad and Tobago", in Ethnonational Politics edited by Steve Fenton and Stephen May, London, Palgrave Macmillan, 2002. 
gaining its votes from the African electorates, this literally triggered an overt stampede for ethnic cover by the electorate.

\section{c. Analysis of the Election Results}

The most significant data in the 1991 elections results show that in an essentially tripartite contest for thirty six (36) seats, the PNM obtained twenty one (21) seats, the UNC thirteen (13) seats and the NAR two (2). The number of votes cast for the three parties were PNM: 234,234; UNC: 151,051 ; and NAR: 126,910 . It was a relatively indecisive result in that no party obtained an absolute majority of the votes cast. The results also suggest the existence of deep divisions in the society marked by persisting ethnic cleavages as well as class dichotomies. Very small margins of victory occurred in a number of constituencies pointing to ambiguity in the PNM victory at a time when a more overwhelming support is needed to cope with the austere economic conditions facing Trinidad.

The 1991 results could be largely explained by a pattern of ethnic preference in voter choice. This was however only an approximate pattern with many interesting variations caused by the fact that the electoral competition was conducted by three main parties of which only the traditional two, the PNM and UNC, were clearly anchored in their respective ethnic communities. The NAR was not ethnically rooted in any constituency; it was essentially a middle class party that had cut across the ethnic divide. Hence the class factor also played an important part. In Tobago East and Tobago West, NAR won its only seats by resounding majorities. Tobago however is a separate kettle of fish from Trinidad. Under NAR's leader ANR Robinson, the island had effectively severed its old PNM attachment and replaced it with an assertive Tobago-centric sub-national collective identity. Hence the NAR vote in Tobago was particular to the island and independent of the party's performance in Trinidad where NAR operated in full competition with the other parties in a multi-ethnic structure. In Trinidad, NAR failed to win a seat in the 1991 elections.

The defeated PNM in the elections of 1986 obtained only 3 out 36 seats in Parliament accounting for $32 \%$ of the votes which in a system of 
Elections, Identity and Ethnic Conflict in the Caribbean:

The Trinidad Case

proportional representation would have earned them about 12 seats out of the 36. The PNM votes in 1986 were constituted almost entirely of AfroTrinidadians in the lower income bracket. It is this cluster that can be legitimately called the "core" traditional PNM group that assumed the form of a permanent popular fixture. To discover the analogous Indianbased UNC core, it is necessary to go back to earlier elections prior to 1981 such as the one in 1961, when the Indians as a cohesive group confronted the other communities in an intense electoral contest. In the 1962 elections, the Indian-based party, the Democratic Labor Party, obtained $42.2 \%$ of the votes, a figure that approximated the $42-43 \%$ that constituted the Indian population of Trinidad. In both the traditional Indian and African parties, the "core" is often conceived as constituted predominantly of about $80 \%$ of lower income persons. It is the middle stratum that is most likely to "float" and it is this middling inter-ethnic cluster that has given rise to parties such as the ONR in 1981 and the NAR in 1991 (the ONR popular vote in 1981 was $22.2 \%$ ). The NAR of 1986 did inherit the ONR group of 1981, but it also succeeded in attracting a wide class base of supporting in its victory over the PNM in 1986. In 1991, the NAR was reduced again to its 1981 ONR self in many salient respects, and the results of 1991 uncannily resembled the results of 1981.

Some of the anticipated NAR victories were projected for traditionally solid UNC Indian electorates. Included among these were notably Chaguanas, Tabaquite, Caroni East, St. Augustine, and Siparia. Had NAR succeeded in those constituencies, it would have severed the ethnic bond in voter preference especially located in the sugar belt and could have led to a radical re-definition of Trinidad's politics as traditionally known. In a number of solid PNM electorates, a similar set of projections were made that included the Diego Martin seats, Arouca North, Arima, and at times even suggestions that two Port of Spain seats which are in the PNM's "sugar belt" would yield to NAR's aggressive campaigning incursions. Had NAR succeeded in penetrating the solid PNM and UNC homelands, then for the first time in the Third World, a conversion from ethnic to class politics would have been achieved. NAR 
had hoped that its appeal to performance in a number of constituencies where it did in fact initiated tangible community programs and employed large numbers of unemployed persons in short term projects that by these criteria it would win votes and overcome open and surreptitious appeals to primordial instincts. In the end, in the heat of the contest, race overcame class criteria by substantial margins.

The NAR ratios cannot be easily dismissed as a passing phenomenon however. In 12 out of 34 constituencies in Trinidad, NAR obtained $25 \%$ or more of the votes cast. In 18 out of Trinidad's 34 seats, NAR obtained the second largest votes. Put differently taking Tobago into consideration, in 20 seats or over $50 \%$ of the constituencies, NAR was either the first and second contender in only 19 seats. In most constituencies, the contest was between NAR on one hand and the PNM on the other. These included most notably cases such as Chaguanas, Diego Martin East, Tabaquite, St. Joseph, Princes Town, St. Augustine and Pointe-à Pierre. In nine cases including Nariva, Fyzabad, Pointe-àPierre, Ortoire-Mayaro, Princes Town, St. Joseph, Tabaquite, St. Augustine, and Tunapuna, it was the NAR vote that prevented an outright majority victor and provided the basis for some closely fought struggles. In the very last week of the elections after the NAR campaign succumbed to the combined assault of the PNM and UNC, it was only then primordial instincts gained momentum that the contest became one between the PNM and UNC, and the results became a forgone conclusion. Up to three weeks prior to the elections, the results predicted by all local pollsters and political commentators attested to a highly fluid contest. No one could and did predict the results accurately.

\section{THE 1995 ELECTIONS}

On December 5, 1995, new elections were unexpectedly called in Trinidad by the ruling PNM. Contrary to the expectations of the ruling party, it lost the elections to the effort of the UNC and NAR. In the 36member House of Representatives, the PNM obtained 17 seats, the UNC 17 seats, and the NAR 2 seats. The NAR had become an essentially Tobago-based party led by Mr. Robinson. In part, the loss of the PNM stemmed from the fact that not enough of its supporters came out to vote 
Elections, Identity and Ethnic Conflict in the Caribbean:

The Trinidad Case

as against the greater mobilization of the UNC. The UNC won narrow victories in two constituencies in Trinidad and therefore was able to equal the number of seats that the PNM obtained. The UNC and the NAR overcame their differences when Mr. Robinson, the NAR leader willingly acceded to the leadership of the new coalition under Indian leader, Basdeo Panday. The significance of the new dispensation as shaky as it was pointed to the possibility of a renewal in inter-ethnic harmony. This however was not too likely since the Creole-based PNM was not part of the coalition government which means that the new Indian-led government has African support only form Tobago, the home of Mr. Robinson. In effect, the fundamental bifurcation and the underlying ethnic animosity in the society were not reconciled in the new government. A more viable inter-ethnic formation was one that must be based on UNC-PNM collaboration. The UNC's invitation to the PNM to join the new government was rejected leaving the new regime standing mainly on the stilt of one ethnic group. It will useful to briefly examine the 1995 elections.

On November 6, 1995 when voters went to the polls for the seventh time since independence in 1961, most observers predicted a normal event in a victory for the predominantly African-based ruling Peoples National Movement (PNM). In what turned out to be a watershed election, the ruling PNM was dramatically ousted from power and replaced by the predominantly Indian-based United National Congress (UNC) in coalition with the smaller party, the National Association for Reconstruction (NAR) making it the first time that an Indian acceded to the Prime Ministership.

In 1995, the essentially two-way contest was a mixture of old and new motifs in Trinidad's politics. The PNM and UNC represented the old ethnic politics; these parties could count on a solid core of ethnic constituents to vote for them. In 1991, NAR was reduced to a shadow of itself as most of its 1986 Indian and African supporters returned to their ethnic camps in the PNM and UNC. In 1995, in an electorate of 837,453 eligible voters, seven parties mounted 114 candidates (with no independent candidate since 1956) for the 36 seats in the National 
Assembly. Of the 36 candidates that the PNM put up, 15 were Indians, 1 White, and the others Africans and Mixed Races. Only one of the PNM's candidates in the Arouca South constituency could be regarded as a sure win while three in St. Joseph, San Juan-Barataria, and San Fernando West were given a fair chance of winning. Of the 34 candidates that the UNC put up, 18 were Indians, 1 White and the others were Africans and Mixed Races. None of the African and Mixed Races UNC candidates was placed in a safe UNC stronghold.

The most significant datum in the 1995 elections shows in a 36member House of Assembly a tie in the seats obtained by the two major parties, 17 for the PNM and 17 for the UNC. NAR captured the remaining 2 seats and therefore held the balance of power. In the past, from 1961 to 1986 and from 1991 to 1995, the PNM won with convincing majorities; in 1986 when the NAR won it obtained 33 out of the 36 seats. A tie was unprecedented and ushered in for the first time the politics of post-election coalition formation. The popular votes received by the main parties showed that no one received a majority of the votes cast. The tiny parties that contested the elections all lost so badly that they lost their deposits. Voter turnout was $63.17 \%$; in 1991 it was $63.39 \%$. Of the voters who cast their ballots, the PNM received $48.35 \%$, an increase of $3.04 \%$ from 1991; the UNC got $45.31 \%$ an increase $16.01 \%$ from 1991 ; and the NAR $4.71 \%$, a decrease of $19.72 \%$ from 1991. While these results underscored the polarized ethnic partisan preferences of the population, just as significantly it undeniably demonstrated that the losses of the NAR party were overwhelmingly gained by the UNC. This was reflected in the increase of the UNC parliamentary seats from 14 to 17 . The gains by the UNC were most profound in a handful of critical constituencies where Indian/African ratios were close.

To an overwhelming degree, ethnic identity determined voter choice in 1995 unlike the 1991 elections when about 15 to $20 \%$ of the population evinced ambivalence as reflected in the NAR vote $(24.43 \%)$, which apart from Tobago was of multi-ethnic derivation. For nearly all the constituencies except 10 , the presence of overwhelming 
Elections, Identity and Ethnic Conflict in the Caribbean:

The Trinidad Case

concentrations of either Indians or Africans pre-ordained the outcome. 15 seats were strongly PNM and 9 UNC with clear ethnic majorities. Together these account for 24 seats and given that the two Tobago seats are personalistically controlled by the NAR leader, Robinson, this leaves 10 seats up for grabs. It would be these 10 constituencies that would decide whether the UNC or PNM won an election. In turn, in these 10 seats, in the 1995 elections, it was the structure of the split of the NAR vote to the UNC and PNM which would substantially determine how these seats went.

Given that the NAR had been rendered virtually impotent in 1995 in the Trinidad constituencies resulting in a two-way race between the UNC and the PNM, how the 1991 NAR support was split between these two parties was absolutely crucial to the outcome of the elections.

Because of the large Indian presence in 4 of the 10 marginal constituencies, Pointe-à-Pierre, Nariva, St. Augustine, and Princes Town, given an emasculated NAR in 1995, it was almost a foregone conclusion that the UNC would take these seats with only a small fraction of the 1991 NAR support. Hence, to the 9 safe UNC seats must be added the additional 4 for a total of 13 seats, meaning that going into the 1995 elections the PNM had 14 sure seats, the UNC 13, and the NAR 2. That left 6 seats in the role of arbiter of the final outcome, namely, Tunapuna, St. Joseph, Fyzabad, San Juan Barataria, Ortoire-Mayaro, and San Fernando West. In the end, the PNM would take 2 of these, Tunapuna by a margin of 244 votes and San Fernando West by 1,288 votes. The UNC would take the remaining 4, two by small margins (St. Joseph by 614 votes and Ortoire-Mayaro by 900) and two by more substantial leads (Fyzabad by 2,197 and San Juan Barataria by 1,183).

The 17-17-2 result ("a state of betweenity" as it was referred to) imposed the demand for a coalition government, the first in Trinidad and Tobago's history. Robinson and NAR who were comprehensively defeated in 1991 held the balance with their two Tobago seats. While it was true that the UNC and NAR leaders met prior to the elections and agreed to cooperate in the defeat of the PNM, the arrangement was very informal and incomplete in part because of the improbability of 
vanquishing the formidable and well financed PNM, even in attaining a minimal 17-17-2 result. To be sure, Panday just about a week before the election polls had publicly predicted a 17-17-2 result even though all the public opinion projections declared the PNM a foregone winner. After the vote, Robinson now holding the balance in the face of no firm undertaking to join the UNC in forming the next government, the country was thrown into two days of speculation about the shape of the next government or whether the electorate had to return to the polls. Robinson and Manning however were not on good personal terms.

The UNC-NAR coalition acceded to power on December 8 with Panday as Prime Minister and Robinson as "Minister Extraordinaire", an ambiguous title. The coalition agreement which was made public proposed that the PNM secret arrangement with the Tobago House of Assembly on devolution be set aside and a new formula be enacted around the recommendations of House Paper No. 6 of 1978 under which Tobago would be accorded substantial self-government. In effect, this would consolidate Robinson's base in the greater autonomy of Tobago. Calling itself a coalition "party of partners" and not a fusion of parties, the agreement also contained provisions for resolving inter UNC-NAR conflicts and consolidating their cooperation.

The Panday-led coalition government which brought for the first time an Indian and a trade unionist to power potentially represented striking if not radical departures from the past. In particular, the ascension of an Indian to the Prime Ministership carried the greatest anxiety especially for the African community long accustomed to the idea of a Creole chief executive as a sort of rightful inheritance. Above all, the future of the UNC-led coalition would be at the mercy of AfricanIndian relations. The fact of an Indian Prime Minister was fraught with symbolism of power and domination, an intangible factor of potentially explosive implications in the proportions of an all out civil war. Much nervousness and malaise prevailed in Port of Spain and the PNM strongholds after the cliff-hanger election results were announced in favor of the UNC. The very indecisiveness of the results generated instability. While Panday was announcing that "it was time to love 
Elections, Identity and Ethnic Conflict in the Caribbean:

The Trinidad Case

again" as he embraced with Robinson reminiscent of the "one love" campaign that the two leaders had conduced in 1986 to bring the NAR to power, the situation was tense and unstable throughout the country in the wake of the election results.

\section{E. RETURN TO ETHNIC PARTISAN POLARISATION:}

THE 2000, 2001 AND 2002 ELECTIONS

\section{a. The 2000 Elections}

In the 1995 general elections, a traumatic event had occurred to the dominant African community when the leader of the rival Indian section which had never captured power before unexpectedly won at the polls. It seemed that a revolution had occurred and for a while the polity hovered nervously on the brink of civil strife. While cool heads prevailed and permitted the victorious party to complete its term in office, the defeated party and its saddened cultural section vowed to reclaim power in the elections of 2000. In part, it was this expectation, along with the fear of the Afro-Creole losing power permanently and consequently being ghettoized and dominated by its ethnic Indo-Creole adversary, that imparted a special tension to the tenor of the elections. While the AfroCreole dominated party, the People's National Movement (PNM), mounted a massive campaign charging the preponderantly Indo-Creole party, the United National Congress, as hopelessly corrupt and completely lacking in morality, more was at issue in the election campaign that was shaping up as a surrogate of cultural warfare. The Afro-Creole community which had traditionally controlled the government and enjoyed the benefits of jobs and patronage from the public bureaucracy, feared that another electoral loss to the UNC would open the way to the takeover of its territorial preserve in the public sector. Hence, the general elections were about both symbolic and instrumental values which together suggested total stakes were at play instead of limited issues and negotiable pragmatic differences. Paradoxically, in this cultural contest, neither political party displayed any program that appealed only to one community. Cross-cultural presentations were the norm that was artfully cultivated as a façade that 
really fooled no one. Knowing it could count on their allegiance and calculating that it needed about 15 to $20 \%$ of the Afro-Creole vote to win, the incumbent Indian-based UNC vehemently abjured any special identity with the Indian community in its public campaign making its message to the electorate: "Performance beats Ole Talk Anytime" and "You Cannot take race to the Grocery Store".

In a House of Representatives constituted of 36 seats, the UNC won 19, the PNM 16, and NAR 1, thus returning Panday as Prime Minister for a second term, a feat that was not achieved since 1986. In an electorate of 947,689 , voter turnout was about $63 \%$ not remarkably different from similar general elections in recent years. The portion that was received by the UNC was 307,537 and the PNM 276,202; this compared favorably with the 1995 results in which the UNC got 240,372 and the PNM 256,159, that is, the defeated PNM in 1995 obtained more votes than the UNC when both parties garnered 17 seats each. In 2000 , the UNC moved ahead of the PNM on popular votes in part because of the new voters in 2000, the UNC obtained 67,000 while the PNM only about 20,000. The UNC had grown not only in popular votes from 1995 to 2000 but also in seats from 17 to 19 while the PNM diminished from 17 to 16. The PNM however did make a breakthrough in Tobago, taking since 1978 one of the two seats from the old bastion of the NAR.

The party dynamics in 2000 shifted significantly from 1995 when the NAR played a pivot role taking both seats in Tobago and assisting the UNC in taking a couple of seats in Trinidad, and above all in bringing Panday to power when it formed a coalition government with the $\mathrm{UNC}^{14}$. In 2000, NAR dropped out in Trinidad confining its campaign to Tobago. During the tenure of the Panday-led coalition with NAR, the two parties disagreed and the relationship fell apart but not before the Panday government had successfully wooed two PNM members of Parliament to its fold.

\footnotetext{
${ }^{14}$ Ralph Premdas, "Elections and Campaigns in a racially Bifurcated State", Journal of Inter-American Studies and World Affairs, 1972.
} 
Elections, Identity and Ethnic Conflict in the Caribbean:

The Trinidad Case

In the coalition deal, Robinson, the NAR leader, was rewarded by Panday with the Presidency of Trinidad and Tobago in exchange for his supporting Panday for the Prime Ministership. However, without its leader, NAR practically fell apart, some of its functionaries siding with the PNM but most with the UNC thereby becoming a splintered shattered force in shaping the outcome of the elections of 2000.

Ethnic identity preponderantly determines party preference in the contest for the 34 seats in Trinidad. In an electoral system of first past the post simple plurality, if the ethnic distribution of a constituency is known before hand, then it is a foregone conclusion that either the PNM or UNC will win. To be sure, there are some critical variations in this pattern related to the presence of substantial numbers of Indian Muslims and Mixed Races. Since NAR was formed in 1986, it tended to garner to its fold a substantial number of persons who were mixed ancestry, but in 2000, with NAR absent from Trinidad, these persons were left to decide their new party affiliation. With regard to Indo-Muslims, they constitute about $15 \%$ of the total Indian population, most of whom are Hindus. In the past, a substantial number of the Indo-Muslims voted for the PNM, but in the past two elections this started to change in favor of the UNC. In a couple of marginal constituencies where the African-Indian population was close, the presence of Muslims as in the case of Barataria/San Juan and San Fernando West proved decisive in favor of the UNC in 2000. In any event, the impact of Indo-Muslims and Mixed Races was important only in a few constituencies. By and large, for 29 out of the 34 electorates on the island of Trinidad, because of the preponderance of either Indians or Africans, party victory for the UNC or PNM was foreordained.

Five constituencies in Trinidad held the balance of power in the outcome of the elections: Tunapuna, Barataria/San Juan, St. Joseph, Ortoire-Mayaro, and San Fernando West. These five constituencies became the targeted battleground between the UNC and PNM submitted to intense artillery of campaigning pressure reaching saturation point in the distribution of flyers, and door-to-door canvassing. In the 1995 elections, the UNC won three of these constituencies and the PNM two. 
In 2000 , the UNC won them all. It was never clear however which seat would have gone decisively for either party before the elections with polls providing conflicting projections. Tunapuna and Barataria/San Juan were fiercely contested. The PNM won the Tanapuna seat in 1995 by only 250 votes and until very recently, the PNM had controlled the Barataria/San Juan seat which has a high concentration of Indo-Muslims. The marginal seat of San Fernando West which was won handsomely by the PNM in 1995 was seen by most observers as a PNM sure victory only to be disappointed by a huge swing in favor of the UNC. In all five of these marginal constituencies, the UNC placed very powerful and popular personalities as its candidate which probably accounted for a small swing that was decisive.

With victory in the five marginal seats, the UNC compiled the necessary 19 seats to give it an absolute majority in the House of Representatives. The UNC won. Importantly, the UNC obtained all its seats from island of Trinidad and unlike 1995 when it depended on two seats from Tobago, it dispensed with the coalition assistance from its sister isle, Tobago. The Trinidad-based victory by the UNC meant also that the 17-17 tie that eventuated in 1995 and that gave Tobago the balance of power now conferred on it autonomy in putting a government in place without coalitions. Some analysts had predicted another 17-17 tie in 2000 which would have favored the PNM since the cordial relationship between NAR and UNC had been destroyed. In the elections on Tobago, the PNM did take one of the two seats and by a small margin nearly won the other. Still that would have only given the PNM 17 seats less than a majority to form a government.

Both the UNC and PNM won convincingly in the 29 Trinidad electorates which had majorities of either Indians or Africans. There are some important observations which emerge from the results in these constituencies. As compared with 1995, the UNC obtained more votes in 2000. In particular, in four previously safe PNM constituencies - San Fernando East, Toco-Manzanella, La Brea, and Point Fortin -, the UNC made such significant inroads that these seats have been converted into new marginal seats in the next elections. The safe UNC constituencies 
Elections, Identity and Ethnic Conflict in the Caribbean:

The Trinidad Case

remained free from similar threats from the PNM. It was clear from all these figures that the UNC was in the ascendancy while a clear decline in the fortunes of the PNM was quite discernible.

Finally, what made the elections more intriguing than most was that after the polling was completed and the UNC declared the winner, the challenge by the PNM regarding the citizenship eligibility qualifications of the two victorious UNC candidates to sit in Parliament literally placed the outcome in abeyance pending the court challenge which would take time. A court decision in the PNM favor could well reverse the fortunes of the Opposition party turning it into the victor. What would also assume a particularly grating post-election feature was the charge that the UNC had engaged in extensive voter fraudulence daubed "voter padding". Indeed, the PNM's leader, Patrick Manning, declared the UNC government illegitimately in office because of the alleged voter irregularity. The elections were not over then with the casting of the last ballot and the counting of the last vote. Communal tension rose high when these issues were compounded by the President of the Republic, Arthur Robinson, refusing to accede to the nomination of seven candidates supplied by the Prime Minister for appointment to the Senate. The fact that the President was Afro-Creole and the Prime Minister was Indo-Creole became the main prism through which the Senate appointment issue was perceived by deeply ethnically divided population. Engulfed by these uncertainties and threats by the Opposition PNM to mount demonstrations, the UNC leader and Prime Minister announced on television that there was a plot to overthrow his new government. The nation palpably was tottering on civil and communal strife.

\section{b. The 2001 Elections}

In exactly a year after the UNC victory on December 11, 2001, the government of Basdeo Panday collapsed and new elections were called. What triggered the downfall related to a succession issue in anticipation of Panday's retirement. The Prime Minister who was 68 years old and a survivor of triple heart bypass operation felt that the UNC ought to undertake a democratic process of selecting his successor. 
He therefore called for a party primary on June 1, 2001 hardly suspecting that the event would tear the UNC into factions that engaged in bitter infighting. The upshot was that three parliamentary members calling themselves Team Unity (TU) were expelled from the party and aligned themselves with the Opposition PNM, and hence without a majority, the UNC called new elections. In addition, the court case that challenged the credentials of 2 UNC parliamentarians on the citizenship issue was not going well for the UNC before the judiciary and there was a fair chance that the UNC on losing the case would be in untenable position to govern.

The issues in the campaign were very much the same as they were for the 2000 elections, performance claimed by the UNC and corruption and "voter padding" charged by the PNM, except in this case, Team Unity constituted itself as a separate political party and entered the fray draining off a small but significant number of UNC votes. The upshot was that both the UNC and PNM received 18 seats creating an unprecedented tie in the 36 member House of Assembly. The PNM had succeeded in winning two additional seats (Tunapuna and Tobago East) but still obtained some 19,341 votes than the UNC overall. Team Unity failed to win a seat but it had taken away votes from the UNC in at least one marginal constituency (Tunapuna) enabling the PNM to win a seat. What was repeated in the elections was the ethnic voting pattern with marginal mixed constituencies determining the final numbers of seats.

It was up to President Robinson to select one of the two party leaders as the Prime Minister on the basis of whichever is likely to command a majority in the evenly divided Parliament. Calling upon Panday and Manning to agree on some sort of compromise to break the deadlock and then failing to do so, the matter was left for the President to decide. However, it is important to note that despite the stalemate, the two parties did agree to a set of post-appointment actions and policies to be implemented regardless of who got the final nod. President Robinson unexpectedly appointed Patrick Manning Prime Minister. This event caused an enormous outburst of protest from the UNC which felt that as the incumbent government that was not defeated in the elections, it ought 
Elections, Identity and Ethnic Conflict in the Caribbean:

The Trinidad Case

to have been re-appointed. In protest, Panday refused to accept the position of Leader of the Opposition. With an 18-18 split, it was clearly just a matter of time when new elections would have to be called again. This was scheduled for October 2002.

\section{c. The October 2002 Elections}

During its short tenure from December 2001 to October 2002, the new PNM government appointed several Commissions of Inquiry to look into its allegations of corruption and voter padding. In drawn out partisan and biased public inquiries, it succeeded in severely tarnishing the image of the UNC. In addition, the PNM in preparation for the next electoral encounter spared no effort in spending public funds lavishly to endear itself to the electorate especially voters in the marginal constituencies. In a tense ethnically inflamed campaign, the election-weary electorate gave the PNM victory with 20 seats and the UNC 16. Again, ethnic voting preference predominated but this time for a variety of reasons the PNM won more marginal constituencies than the UNC.

\section{F. CONCLusion}

On a larger canvass, a more basic set of issues was engaged by the general elections in Trinidad. Specifically, stemming from the potential of ethnic conflict to frustrate efforts at development, should openly competitive elections to secure a legitimate government be retained? Elections in the plural societies of the Third World tend to involve destructive collective communal struggles among sectionally based parties ${ }^{15}$. Sir Arthur Lewis, the Caribbean Nobel Laureate, identified communal conflict and identity politics as the single most significant factor that inhibited Third World Development. Said Lewis: "[...] each country contains several tribes, living at different economic levels. Tribal consciousness and economic differences combine to produce mutual antagonisms which menace the unity of the state"16 "The

\footnotetext{
${ }^{15}$ Ralph Premdas, «Elections and Campaigns in a Racially Bifurcated State », Journal of Inter-American Studies and World Affairs, 1972.

${ }^{16}$ W. Arthur Lewis, Politics in West Africa, London, Allen and Unwin, 1965, p. 49.
} 
fundamental problem is neither economic nor foreign policy, but the creation of nations out of heterogeneous peoples" ${ }^{\text {"17 }}$.

Communal conflict tends to be built on several coinciding cleavages such as culture, language, religion, race, etc. In Trinidad, the ethnic matrices were erected around race, religion and culture. These discrete features provided the boundaries of identity construction creating communal compartments which are exploited during elections for office. Democratic elections in an open system of discourses invite appeals for vote based on ethnic identity. In the give and take of the electoral campaign, negative ethnic stereotypes are often invoked and manipulated for votes. Consequently, inter-sectional animosity and distrust rise to new levels at election time. After the elections are over, the ethnic distrust that was cultivated does not disappear but are retained as a residue on which new fears are built. Hence, over several competitive open elections, the level of ethnic fear grows in a game over which the spoils of victory assume greater importance. In the zero-sum contest for votes, more than just office and jobs are at stake, even important as these are. The arousal of inter-ethnic fears over several successive elections tends to destroy the basis of trust in a government captured by one or the other ethnic group. Together then, the zero-sum structure of the electoral contest as well as the increasing momentum of inter-ethnic fears over several elections create the incendiary basis for an ethnic conflagration.

${ }^{17}$ Ibid. 


\begin{abstract}
Imported into Trinidad from British roots, an environment radically different in social structure from Trinidad, the adaptation of the electoral device to the multi-ethnic society of Trinidad and Tobago has left important questions unresolved about the roles of representation, identity, integration, and citizen commitment to the political order.

The electoral system was based on zero-sum competition for popular support. In particular, representation tends to become communalized so that the party in power symbolizes not the public will at large but sectional solidarity and ethnically particularized interests. Citizen commitment is passionately expressed but communally cleaved so that only one section at a time identifies with the governing regime. The out-section is alienated. Hence, elections elicit fearsome primordial responses and deeply divisive fears in culturally fractured states.
\end{abstract}

In a communally-divided society lacking shared beliefs and identities, all political structures however neutrally designed tend to be tainted and imbued with suspect ethnic motifs and interests. Communal identities are at stake for in defeat the

\section{RESUME}

Importé à Trinidad - dans un environnement social radicalement différent - à partir des racines britanniques, le dispositif électoral, tel qu'il a été adapté à la société multiethnique de Trinidad et Tobago, a laissé en suspens des questions importantes relatives aux rôles de la représentation, de l'identité, de l'intégration et de l'implication citoyenne dans l'ordre politique.

S'agissant du soutien populaire, le système électoral était basé sur le principe d'une compétition à somme nulle. En particulier, la représentation a tendance à être communalisée, de sorte que le parti au pouvoir incarne non pas la volonté générale mais des solidarités et des intérêts ethniques particularisés. L'engagement citoyen s'exprime avec passion, mais sur le fondement de clivages communautaires, de sorte qu'un seul groupe à la fois s'identifie au gouvernement. Par conséquent, les élections suscitent de redoutables réponses primordialistes et des craintes qui divisent profondément dans des états culturellement fragmentés.

Dans une société segmentée et divisée, manquant de croyances et d'identités partagées, toutes les 
vanquished may witness the marginalization of its way of life. Consequently, the electoral device becomes larger than its original purpose designed for selecting decision-makers.

In Trinidad, it was charged that elections became an arena of contesting identities enmeshed in a threat of ethnic domination. The pivotal problem thrown up by Trinidad's multi-ethnicity in part pertains to collective communal interests and sectional identity. Each ethnic section sees its interests differently not only in relation to its symbolic and cultural life but in relation to claims to economic resources. Each election that came tended to raise anew all the unresolved issues of ethnic equity. As it happened in Trinidad, one ethnic group in an essentially ethnically bipolar state had captured power and in the perception of the other major ethnic community instituted an order that was ethnically repressive and discriminatory.

An election campaign assumed the form of identity rivalry expressed in a collective communal struggle in which the claims of each community as a whole reignited anew and expressed in uncompromising terms. Repeated victory by one sectional community over the other was not accepted by the vanquished group which withdrew its moral support from the state. structures politiques conçues pour être neutres tendent à être viciées et imprégnées de considérations et d'intérêts ethniques suspects. Des identités communautaires sont en jeu car, dans la défaite, les vaincus peuvent faire l'expérience de la marginalisation. Par conséquent, le dispositif électoral va au-delà de sa fonction initiale qui est de choisir des décideurs.

A Trinidad, les élections sont devenues une arène où les identités s'affrontent, sous la menace d'une domination ethnique. Le problème central posé par la multiethnicité trinidadienne concerne en partie les intérêts communautaires collectifs et l'identité segmentée. Chaque communauté ethnique voit ses intérêts différemment, non seulement au regard de sa vie symbolique et culturelle, mais aussi par rapport aux revendications portant sur les ressources économiques. Chaque élection a eu tendance à soulever de manière récurrente toutes les questions d'équité non résolues du point de vue de l'appartenance ethnique. Comme ce fut le cas à Trinidad, un groupe ethnique dans un Etat fondamentalement caractérisé par une bipolarisation ethnique a capté le pouvoir et a institué un ordre perçu par l'autre communauté ethnique principale comme étant répressif et discriminatoire.

Une campagne électorale a entériné la compétition entre identités rivales qui s'exprime dans une lutte communautaire collective dans 
Elections, Identity and Ethnic Conflict in the Caribbean:

The Trinidad Case

laquelle les revendications de chaque communauté en tant que telle ont été de nouveau relancées et présentées en des termes intransigeants. Les victoires répétées de l'un des segments communautaires sur l'autre n'ont pas été acceptées par les vaincus qui ont retiré leur soutien moral à l'Etat. 